\title{
KONTRIBUSI ORGANIZATION CITIZENSHIP BEHAVIOR (OCB) TERHADAP TEAM VIABILITY PADA TIM KERJA
}

\author{
Yanies Novira Soedarmadi \\ Prodi Psikologi, Fakultas Bisnis,Psikologi \& Komunikasi, Universitas Teknologi Yogyakarta, \\ Jl. Siliwangi (Ringroad Utara), Jombor, Sleman D.I Yogyakarta, 55285 \\ Email: yanies.novira@staff.uty.ac.id
}

\begin{abstract}
Abstrak
Perubahan paradigma kerja konvensional menjadi bentuk kerja tim yang terdiri dari penggabungan kemampuan unik individu-individu dan kemampuan bekerja secara dinamis dalam menjawab tantangan lingkungan yang kompleks, dapat membawa dampak positif pada produktivitas dan kinerja organisasi. Masalah timbul ketika tim kerja tidak lagi bersedia bekerjasama dan mengulang kinerja positif seperti sebelumnya. Pengetahuan mengenai kelangsungan hidup tim dimasa yang akan datang atau team viability menjadi hal yang penting guna mengelola tim kerja, serta menjaga produktivitas dan kinerja organisasi tetap optimal. Salah satu faktor yang menunjang team viability adalah terdapatnya perilaku keorganisasian atau Organizational Citizenship Behavior (OCB), maka pada penelitian ini bertujuan untuk mengetahui bagaimana hubungan $O C B$ dan team viability pada tim kerja. Pengukuran dilakukan dengan menggunakan model skala Likert yang terdiri atas skala OCB dan Skala Team Viability. Subjek pada penelitian ini berjumlah 60 orang dan tengah bekerja pada suatu tim kerja, dengan masa kerja minimal 1 tahun. OCB memberikan kontribusi terhadap team viability sebesar $48,8 \%$ dan selebihnya dipengaruhi oleh faktor-faktor lainnya. Hasil penelitian menunjukkan terdapat hubungan yang signifikan positif antara OCB dan team viability $(r=0,699)$. Berdasarkan deskripsi data penelitian didapatkan OCB dan team viability beserta aspek-aspeknya didapatkan nilai-nilai skor yang bervariasi. Aspek OCB berupa helping behavior, sportsmanship, dan respon afektif memiliki kategori nilai skor tinggi, sedangkan civic virtue yang memiliki kategori nilai skor sedang hingga rendah. Kategori nilai skor sedang juga terdapat pada aspek team viability yaitu respon interpersonal.
\end{abstract}

Kata Kunci : organizationship citizenship behavior, team viability

\section{CONTRIBUTION OF ORGANIZATION CITIZENSHIP BEHAVIOR (OCB) TOWARDS TEAM VIABILITY AMONG WORK TEAMS}

\begin{abstract}
Work paradigm change into a form of team work brings positive impact on productivity and organizational performance. Knowledge about the survival of the team in the future or team viability becomes important for taking the next step in managing the work team. There are several factors to support the presence of a viability teams, one of which is organizational behavior. This research was designed to examine relationship between OCB and team viability in a teamwork. Both of OCB and team viability were measured by Likert's scale model which consists of OCB scale and team viability scale. 60 participants who participated on this research were a team worker who worked more than a year. The result showed a significant positive correlation between $O C B$ and team viability $(r=0,699)$. The result also showed $O C B$ contributed $48,8 \%$ team viability of teamwork member's. And the rest was contributed by other factors. Both of the variables based on subjects description data have high scores categories. The aspects are helping behavior, sportsmanship, and affective response. However there are some differences between other OCB's and team viability's aspects. They are civic virtue and interpersonal scale which have low and middle scores.
\end{abstract}

Keywords: organizationship citizenship behavior, team viability 


\section{Pendahuluan}

Globalisasi dan perkembangan teknologi informasi yang cepat menggiring dunia pada banyaknya perubahan. Akibatnya kompetisi makin ketat salah satunya bagi organisasi yang bergelut di dunia industri. Tuntutan permintaan pasar yang meningkat baik dari segi kualitas maupun kuantitas, ditambah dengan keberadaan lingkungan yang bersifat semakin kompleks. Perusahaan dituntut untuk memiliki kinerja yang optimal dan produktivitas yang tinggi serta bersifat kompetitif. Terjadi perubahan paradigma kerja perusahaan dari sistem kerja konvensional berupa model kerja individual menjadi lebih lateral yaitu berdasarkan model tim kerja. Naquin dan Tynan (2003) menyebutkan bahwa tim kerja memiliki performansi yang baik dalam pasar yang sangat kompetitif. Salah satu keunggulan model tim kerja ini dianggap mampu mengimbangi tuntutan semakin kompleksnya pasar. Tim menyediakan suatu alat yang terbaik dari penggabungan kemampuan-kemampuan unik pada individu dalam menciptakan performansi yang lebih baik.

Tantangan yang dihadapi tim-tim kerja tidak sedikit mengingat kondisi pasar dan persaingan yang tinggi baik di dalam maupun di luar negeri. Misalnya permasalahan yang terjadi pada perusahaanperusahaan perintis teknologi atau disebut start-up seperti yang dilansir dalam website CNBC Indonesia (2018), menyebutkan bahwa sebanyak 65\% perusahaan gagal tumbuh karena persoalan internal berupa masalah dalam tim kerja, diantaranya seperti masalah interpersonal antar anggota tim maupun anggota tim dengan atasannya. Masalah interpersonal yang muncul seperti komunikasi yang kurang harmonis, silang pendapat dan sikap antara anggota tim, sehingga anggota tim memilih untuk mundur dari tim kerja yang telah dibangun dalam waktu panjang.

Permasalahan mengenai tim kerja khususnya terkait keberlangsungan tim kerja, tidak hanya dihadapi oleh perusahaan teknologi informasi saja, namun hampir semua perusahaan industri. Kerjasama dalam sebuah tim kerja dituntut untuk dapat berlangsung dalam jangka waktu lama, dan masing-masing anggotanya tidak hanya mengerjakan satu tugas spesifik saja namun juga menangani berbagai jenis aktivitas (Bell \& Marentette, 2011). Pengetahuan mengenai kualitas anggota yang sanggup dan ingin bertahan dalam tim kerjanya setelah melalui aktivitas bekerja bersama-sama dalam satu waktu, sangat dibutuhkan untuk mengetahui kekuatan perusahaan. Pengetahuan mengenai keberlanjutan tim dimasa yang akan datang berguna untuk pengambilan langkah selanjutnya. Hackman (1987) mencetuskan teori I-P-O mengenai keefektifan suatu tim kerja dapat dilihat dari output yang terdiri dari performansi tim itu sendiri dan output lainnya. Output lainnya ini disebut oleh Hackman (1987) dalam Page (2004) berupa pemahaman mengenai keefektifan tim di masa depan, yaitu berupa team viability.

Team viability secara harafiah dapat diartikan sebagai kelangsungan hidup tim. Viability berasal dari kata viabilitas yang berarti kemungkinan untuk mampu hidup. Page (2004) selanjutnya menyebutkan bahwa team viability merupakan bentuk dari keefektifan tim yang diukur sepanjang waktu, yaitu merupakan kemampuan tim untuk kembali melanjutkan bekerja sama lagi. Kreitner dan Kinicki (2001) mengadopsi teori yang dikemukakan oleh Sundstrom, dkk (1990) dimana ia mendefinisikan team viability sebagai kepuasan anggota tim yang kemudian dilanjutkan dengan keinginan mereka untuk berkontribusi kembali di dalam tim tersebut. Rentsch, dkk (2003) selanjutnya menyebutkan definisi yang bersifat gabungan dari teori-teori yang ada mengenai team viability, dimana ia mendefinisikannya 
sebagai keinginan dan kemampuan tim untuk kembali bekerja sama pada proyek-proyek tim selanjutnya.

Furst, dkk (1999) dalam Schahaf, dkk (2002) menyebutkan bahwa team viability dianggap sebagai komponen kritis dalam pengerjaan suatu pekerjaan yang bersifat kolaboratif oleh tim, dan dibutuhkan selama tim tersebut mengerjakan tugas-tugasnya. Team viability merupakan salah satu dimensi output yang dinilai berdasarkan proses yang telah dijalani sebuah tim. Proses yang dimaksud adalah selama periode anggota tim bekerja sama, yaitu berhubungan dengan tugas yang dikerjakan bersama, konflik, dan juga hal-hal berhubungan lainnya yang mendukung terbentuknya rasa kebersamaan dalam tim tersebut. Proses yang terjadi dalam sebuah tim kerja dapat dinilai dari beberapa aspek yang melibatkan anggota sebuah tim kerja ketika mereka sedang berinteraksi. Menurut Stott \& Walker (1995), disebutkan bahwa apabila suatu tim memiliki kohesivitas yang tinggi, yang berciri memiliki kepercayaan dan rasa tanggung jawab tinggi akan suatu tujuan tim dan pekerjaan, memiliki ketergantungan satu dan lainnya, serta memiliki kepuasan terhadap kinerja dan hubungan antar anggota, maka tim tersebut akan memiliki keinginan untuk melanjutkan bekerjasama dengan tujuan mendapat manfaat secara terus menerus. Team viability ini menurut Kreitner dan Kinicki (2001) merupakan faktor yang muncul dari rasa kepuasan anggotanya yang dilanjutkan dengan keinginan mereka untuk berkontribusi kembali dalam tim tersebut.

Adapun hal-hal yang dapat tampak dan terukur adalah respon yang diberikan anggota tim kerja selama ia bekerja dengan tim kerjanya, sehingga diharapkan team viability pada anggota tim kerja tersebut dapat diketahui. Respon tersebut menurut Gordon, dkk (1999) dalam penelitiannya adalah berupa respon afektif dan interpersonal dari anggota tim kepada timnya tersebut. la mengungkapkan bahwa team viability dapat diukur dengan mengetahui respon afektif maupun respon interpersonal pada suatu tim kerja. Adapun respon afektif yang muncul seperti perasaan ketidakcocokan dengan rekan satu tim, dan hubungan interpersonal berupa komunikasi yang kurang harmonis antar anggota menjadi pemicu munculnya keinginan untuk meninggalkan tim kerja. Baron \& Byrne (2004) menjelaskan respon afektif adalah respon yang berkaitan dengan keadaan emosional seseorang, yaitu perasaan dan suasana hati seseorang. Gordon, dkk (1999) menyebutkan respon afektif ini berkaitan dengan apakah mereka bahagia ketika menjadi bagian dalam tim tersebut, apa yang mereka rasakan ketika melakukan suatu tugas atau berperformansi dengan tim mereka, dan mereka juga diberikan pilihan apakah mereka lebih memilih atau menyukai tim mereka atau lebih memilih menyukai tim kerja lainnya. Kreitner dan Kinicki (2001) juga menunjukkan respon afektif ini melalui penilaian apakah seorang anggota tim kerja tersebut merasakan hal yang lebih baik atau buruk mengenai kontribusinya dalam tim kerja tersebut. Respon interpersonal berkaitan dengan respon pada hubungan antara anggota tim kerja tersebut. Stott \& Walker (1995) mengungkapkan bahwa hubungan interpersonal merupakan salah satu kunci sukses sebuah tim, dimana suatu tim yang sukses didukung oleh hubungan interpersonal yang sehat di dalam tim itu sendiri.

Pemahaman mengenai team viability merupakan hal penting agar organisasi dapat melakukan pengambilan keputusan yang tepat dan meningkatkan produktivitas tim kerja, yang mana merupakan kunci keberhasilan perusahan menghadapi kompetisi dan lingkungan yang semakin kompleks. Tumbuh dan berkembangnya team viability didukung oleh beberapa faktor. Robbins \& Judge (2015) mengungkapkan terdapat beberapa faktor yang dapat membentuk keefektifan tim diantaranya adalah desain kerja, komposisi tim, konteks tim, dan proses yang terdapat di dalam tim tersebut. Faktor-faktor tersebut secara langsung maupun tidak langsung, turut mendukung berkembangnya team viability. 
Salah satu faktor keefektifan tim yaitu proses, suatu tahap dimana selama para anggotanya bekerjasama, telah tumbuh dan berkembang suatu perilaku keorganisasian yang dapat menunjang team viability pada sebuah tim kerja.

Perilaku keorganisasian berupa OCB atau Organizational Citizenship Behavior merupakan perilaku dalam berorganisasi yang dapat membantu membangun sinergi positif dalam tim dan menghasilkan keefektifan tim. OCB dapat membantu mempromosikan tujuan-tujuan organisasi dan meningkatkan secara efektif fungsi-fungsi suatu organisasi. Perilaku keorganisasian dilakukan di luar tuntutan pekerjaan formal dan dilakukan pula tanpa terdapatnya imbalan dari organisasi yang bersangkutan. Misalnya seperti membantu pekerjaan rekan dalam satu tim kerja tanpa mendapat imbalan, yang mana kegiatan sukarela karyawan tersebut dapat memunculkan hubungan yang hangat dan terselesaikannya tugas-tugas tim secara lebih efektif. Organ, dkk 1988 dalam Bachrach, dkk (2001) menyebutkan OCB telah menjadi topik hangat yang banyak menyita perhatian, karena diasumsikan dapat meningkatkan keefektifan sebuah organisasi. Riggio (2003) mengungkapkan bahwa OCB dapat meningkatkan segi koordinasi aktivitas antar anggota tim maupun dengan tim kerja lainnya, yang pada akhirnya dapat meningkatkan keefektifan tim kerja tersebut.

Menurut Organ dalam Shapiro (2002) disebutkan bahwa OCB merupakan perilaku yang kapan saja dapat terjadi, yaitu ketika individu melakukan suatu aktivitas yang membawa dampak positif bagi organisasi secara sukarela, tidak diarahkan atau tersusun secara formal pada sistem penggajian, perilaku ini mempromosikan fungsi-fungsi efektif dari organisasi, bukan pula berupa kebutuhan yang harus dilaksanakan atau tertuang dalam deskripsi pekerjaan, dan perilaku ini lebih mengenai keputusan pribadi seseorang apakah ia mau melakukannya atau tidak. OCB selanjutnya pada penelitian ini didefinisikan sebagai perilaku sukarela anggota tim untuk meningkatkan atau mempromosikan kerja tim dan tujuan-tujuannya, secara formal tidak berada dalam sistem reward, dan memberi kontribusi keefektifan pada fungsi tim kerja. Terdapat banyak pendapat mengenai dimensi OCB yaitu salah satunya seperti yang disebutkan oleh Organ, Podsakoff \& Mackenzie (2006) yang terdiri dari:

1) Altruism yaitu perilaku membantu orang lain secara langsung

2) Conscientiousness yaitu perilaku patuh pada norma organisasi

3) Sportsmanship yaitu perilaku tidak mempermasalahkan masalah yang tidakpenting,

4) Courtesy yaitu mendiskusikan dengan anggota lainnya sebelum mengambil suatu tindakan

5) Civic virtue yaitu bersifat peduli akan hal-hal yang menyangkut tentang organisasi.

Terdapat aspek-aspek yang dimasukkan sebagai aspek OCB dalam konteks tim kerja pada penelitian ini, yaitu :

a. Helping behavior, yaitu perilaku membantu pekerja lain, mencegah sesuatu hal yang buruk terjadi berkaitan dengan pekerjaan mereka.

b. Sportsmanship, yaitu kesanggupan seseorang untuk dapat memaafkan kesalahan yang dilakukan oleh orang lain, dan mentoleransinya walaupun tidak sesuai dengan keadaan idealnya.

c. Civic virtue, yaitu perilaku yang mengindikasikan bahwa seseorang tersebut berpartisipasi dan peduli mengenai kehidupan organisasi.

Pertimbangan menggunakan ketiga aspek tersebut didukung pula dengan penelitian Podsakoff, dkk (2001) yang mengukur keefektifan tim kerja sebagai alternatif penjelasan hubungan antara OCB dengan performansi tim. Podsakoff menjelaskan penggunaan berdasarkan beberapa alasan yaitu: ketiga aspek OCB mencakup helping behavior, sportmanship dan civic virtue 
a. Ketiga aspek tersebut telah terbukti pada penelitian terdahulu memiliki hubungan dengan keefektifan kelompok kerja.

b. Ketiga aspek ini menurut Organ,dkk (2006) merupakan dasar dari konseptual kerja

c. Ketiga aspek ini dianggap bersifat observabel bila digunakan dalam konteks kelompok atau tim kerja.

Pada level tim, OCB dapat tumbuh dan berkembang melalui interaksi antar anggota organisasi. OCB dapat tumbuh karena kepuasan kerja yang dirasakan oleh angggota tim kerja tersebut selama periode bekerja. Terdapatnya aspek-aspek yang dimiliki OCB dapat mendukung terciptanya team viability, yang mana team viability juga merupakan dampak dari kepuasan anggota tim tersebut. Kepuasan anggota tim kerja inilah mendorong anggota tim kerja memiliki keinginan dan kemampuan untuk bertahan dalam tim kerja tersebut. Berdasarkan hal tersebut, diasumsikan ada hubungan positif antara OCB dengan team viability: semakin tinggi $O C B$ yang dimiliki oleh anggota suatu tim kerja maka akan semakin tinggi pula team viability suatu tim kerja tersebut, dan sebaliknya apabila terdapat OCB yang rendah pada sebuah tim keja maka akan rendah pula team viability pada tim tersebut.

\section{Metode}

Subjek pada penelitian ini menggunakan 60 orang karyawan PT. X. Metode pengambilan sampel dilakukan dengan menggunakan metode purposive sampling. Adapun karakteristik subjek dalam penelitian ini adalah:

1. Karyawan yang bekerja sebagai anggota dari tim-tim kerja yang bekerja pada satu proyek dalam waktu tertentu pada satu perusahaan.

2. Tim kerja tersebut memiliki target yang telah ditentukan sebelumnya, seperti target penjualan dan target produksi.

3. Subjek yang dipilih adalah subjek yang telah bekerja minimal selama 1 tahun.

Metode yang digunakan untuk mengumpulkan data OCB dan team viability pada penelitian ini adalah dengan menggunakan metode kuantitatif untuk melihat hubungan antara dua variabel dengan menggunakan instrumen ukur berupa skala. Skala sikap yang digunakan pada penelitian ini adalah skala sikap model Likert. Terdapat dua jenis skala yang digunakan pada penelitian ini yaitu Skala OCB dan Skala Team Viability. Berdasarkan uji coba skala, pada Skala OCB didapatkan 39 butir aitem valid dengan batasan koefisien aitem total $r=0,25$. Koefisien korelasi aitem total dari aitem yang valid pada skala ini bergerak dari $r=0,2528$ sampai dengan $r=0,6609$. Koefisien reliabilitas untuk skala OCB sebesar $r=0,9211$. Pada Skala Team Viability terdapat 40 butir aitem valid dengan batasan koefisien aitem total $r=0,30$. Koefisien korelasi aitem total dari aitem yang valid pada skala ini bergerak dari $r=$ 0,3053 sampai dengan $r=0,7075$, sedangkan koefisien reliabilitas sebesar 0,9330 . Nilai koefisien reliabilitas pada Skala OCB dan Team Viabilty menunjukkan kedua skala tersebut handal dan dapat digunakan sebagai alat mengumpulkan dat penelitian.

Analisis data yang digunakan dalam penelitian ini menggunakan analisis korelasi Product Moment untuk menguji hipotesis dengan melihat hubungan variabel tergantung dan variabel bebas. Analisis dengan teknik korelasi Product Moment dari Pearson ini dapat digunakan apabila, bentuk distribusi variabel-variabel dalam populasi adalah mendekati distribusi normal dan hubungan antara variabelvariabelnya merupakan hubungan garis lurus atau hubungan linier. Uji asumsi berupa uji normalitas dan uji linieritas akan dilakukan untuk memenuhi persyaratan sebelum melakukan uji hipotesis. 
Yanies Novira Soedarmadi

Perhitungan-perhitungan statistik tersebut akan dilakukan dengan komputer dengan menggunakan Statistic Program for Special Science (SPSS) for windows.

\section{Hasil dan pembahasan}

Hipotesis penelitian diuji menggunakan analisis korelasi dengan Product Moment dan didapatkan bahwa nilai korelasi sebesar $r=0,699$ dengan $p=0,000(p<0,005)$. Hasil korelasi yang ini mengandung arti bahwa hipotesis penelitian diterima yaitu ada hubungan positif yang signifikan antara OCB dengan team viability. Berdasarkan hasil pengolahan data tersebut didapatkan pula nilai $\mathrm{R}$ square sebesar 0,488 . Artinya determinasi variabel bebas berupa OCB terhadap variabel tergantung yaitu team viability sebesar $48,8 \%$, dan selebihnya didukung oleh faktor-faktor lain.

Uji hipotesis untuk menguji hubungan antara $\mathrm{OCB}$ dan team viability menunjukkan bahwa hipotesis diterima, yaitu terdapat hubungan yang positif dan signifikan antara OCB dengan team viability $(r=$ 0,699). Hubungan ini menjelaskan bahwa semakin tinggi OCB pada sebuah tim kerja maka semakin tinggi pula team viability dalam tim kerja tersebut. Peningkatan team viability dapat ditunjang dengan hadirnya OCB dalam sebuah tim kerja. Hubungan yang bersifat positif ini dapat dilihat pula dari deskripsi data penelitian yang menunjukkan subjek penelitian memiliki OCB dan team viability yang positif. Hal ini ditunjukkan dari skor data empirik yang lebih tinggi dari pada data hipotetiknya, baik pada variabel OCB maupun team viability. Sebagian besar skor data baik pada variabel OCB dan team viability juga diikuti aspek-aspeknya, memiliki kategorisasi tinggi dan sedang.

Hasil penelitian ini sejalan dengan hasil penelitian yang dilakukan oleh Podsakoff, dkk (2001) mengenai hubungan OCB dengan kelompok kerja dalam setting kinerja organisasi, dimana terdapat hubungan antara OCB dengan keefektifan tim atau unit kerja. Perbedaan dengan penelitian Podsakoff, dkk (2001) yaitu pada penelitian ini mampu menunjukkan hubungan OCB dengan salah satu kriteria keefektifan tim kerja berupa team viability, yang berguna bagi organisasi untuk dapat memahami dan memprediksi bagaimana keberlangsungan suatu tim kerja di masa yang akan datang. Barrick dan Stewart (1998) menjelaskan terdapat beberapa kriteria keefektifan tim salah satunya adalah terdapatnya team viability. Selanjutnya hubungan antara OCB dan team viability dapat dijabarkan melalui data deskriptik kuantitatif. Berikut deskripsi data yang menunjukkan sebaran data mengenai subjek dalam penelitian ini. 
Kontribusi Organization Citizenship Behavior (OCB) Terhadap Team Viability Pada Tim Kerja Proyeksi, Vol. 14 (2) 2019, 105-114

Tabel 1. Deskripsi data hipotetik

\begin{tabular}{|c|c|c|c|c|c|}
\hline \multirow{3}{*}{ No } & \multirow{3}{*}{ Variabel } & \multicolumn{4}{|c|}{ Data Hipotetik } \\
\hline & & \multicolumn{3}{|c|}{ Skor } & \multirow{2}{*}{ SD } \\
\hline & & Min & Max & $\mathbf{M}$ & \\
\hline 1 & OCB & 39 & 195 & 117 & 26 \\
\hline 2 & Helping Behavior & 16 & 80 & 48 & 10,7 \\
\hline 3 & Sportmanship & 15 & 75 & 45 & 10 \\
\hline 4 & Civic Virtue & 9 & 45 & 27 & 6 \\
\hline 5 & Team Viability & 40 & 200 & 120 & 26,7 \\
\hline 6 & Respon Afektif & 21 & 105 & 63 & 14 \\
\hline 7 & Respon Interpersonal & 19 & 95 & 57 & 12,7 \\
\hline
\end{tabular}

Tabel 2. Deskripsi data empirik

\begin{tabular}{llcccc}
\hline & & \multicolumn{3}{c}{ Data Empirik } \\
\cline { 3 - 5 } No & \multicolumn{3}{c}{ Variabel } & \multicolumn{3}{c}{ Skor } & SD \\
\cline { 3 - 5 } & & Min & Max & M & 20,3 \\
\hline 1 & OCB & 114 & 183 & 147,9 & 9,2 \\
2 & Helping Behavior & 42 & 79 & 62 & 7,3 \\
3 & Sportmanship & 40 & 69 & 55,9 & 6,2 \\
4 & Civic Virtue & 18 & 40 & 30 & 24,2 \\
5 & Team Viability & 114 & 193 & 145,6 & 13,4 \\
6 & Respon Afektif & 57 & 101 & 77,9 & 11,3 \\
7 & Respon Interpersonal & 51 & 92 & 67,7 & \\
\hline
\end{tabular}

Berdasarkan hasil analisis statistik deskriptif, didapatkan skor yang tinggi pada helping behavior dan sportmanship, kedua aspek yang terdapat dalam OCB ini dapat meningkatkan sikap tolong menolong dalam tim kerja dan aspek sportsmanship dapat meningkatkan rasa toleransi terhadap anggota tim kerja. OCB dalam hal ini berperan membantu tim kerja dengan menciptakan hubungan yang erat, bersifat nyaman, menyenangkan dan terdapat terdapat koordinasi yang baik melalui aspek-aspeknya tersebut. Hal ini akan meningkatkan keinginan anggota tim tersebut untuk tetap bergabung dan bekerja bersama dalam tim. Penelitian Nawaz \& Gomes (2018) menyebutkan bahwa OCB dapat 
memfasilitasi performansi tim kerja untuk dapat memberikan performansi kerja yang memadai. Sedangkan pada aspek civic virtue sebagian besar memiliki kategori skor yang berkategori sedang bahkan terdapat kategori skor rendah. Hal tersebut menunjukkan kepedulian karyawan terhadap tim kerja maupun perusahaan tergolong rendah. Kepedulian karyawan yang rendah ini dapat disebabkan oleh kurangnya rasa memiliki atas perusahaan, karyawan hanya bekerja sesuai dengan tugas yang diberikan dan menganggap tidak penting hal-hal di luar tanggung jawabnya yang mana sebenarnya dapat mempengaruhi produktivitas perusahaan.

Hasil analisis statistik deskriptif pada skor aspek-aspek team viability yaitu respon afektif menunjukkan kategori skor yang dominan tinggi dan respon interpersonal yang dominan berkategori skor sedang. Respon interpersonal memiliki kategori skor yang lebih rendah dari pada respon afektif dapat dikarenakan oleh aspek civic virtue subjek yang mencerminkan rasa kepedulian memiliki nilai yang cenderung rendah. Dampak kurangnya rasa kepedulian ini dapat terlihat pada hubungan yang bersifat kurang menyenangkan diantara beberapa anggota tim kerja, terutama pekerja yang tidak memiliki latar belakang yang sama, sehingga respon interpersonal yang tampak belum cukup memuaskan.

Berdasarkan hal tersebuat dapat dilihat bahwa OCB tumbuh dengan sendirinya melalui interaksi dan kebersamaan yang kerap terjadi diantara para pekerja. Faktor persamaan latar belakang budaya, tempat tinggal dan hubungan tali saudara juga mendukung berkembangnya OCB. Terdapatnya OCB dalam sebuah tim kerja dihasilkan oleh tumbuhnya rasa kebersamaan dan rasa memiliki, hal ini tercermin dari aspek-aspek OCB berupa rasa saling menolong, toleransi dan kepedulian antara anggota tim kerja. Perasaan ini kemudian yang dapat mendukung seorang anggota tim kerja untuk tetap bertahan dalam tim kerjanya. Determinasi OCB kepada team viability dalam hal ini bersifat tidak sepenuhnya, terdapat variabel lainnya seperti faktor kepribadian, kepemimpinan, sistem penggajian, dan jenis tugas kerja, yang dapat memberikan sumbangan pada team viability. Berdasarkan perhitungan didapatkan nilai $\mathrm{R}$ Square sebesar 0,488 yang berarti determinasi OCB terhadap team viability hanya sebesar $48,8 \%$ dan selebihnya terdapat variabel lain yang menentukan team viability. Faktor-faktor yang berpengaruh lainnya menurut Robbins \& Judge (2015) dapat berupa desain kerja, komposisi tim, konteks tim dan proses yang terjadi dalam tim. Faktor-faktor tersebut masing-masing memiliki komponen yang berisi variabel-variabel yang dapat menentukan team viability, misalnya kepribadian, kepemimipinan, sistem penggajian yang adil, ukuran tim, struktur organisasi, iklim kepercayaan anggota tim, dll.

Hubungan pada kedua variabel menunjukkan keberadaan OCB pada suatu tim kerja dapat membantu meningkatkan team viability, dimana team viability dapat memprediksi kinerja dan merencanakan strategi tim kerja dimasa depan. Hal ini secara tidak langsung membantu meningkatkan keefektifan tim kerja dan produktivitasnya. Pengetahuan ini selanjutnya berguna bagi pengembangan keorganisasian.

\section{Kesimpulan}

Penelitian ini menunjukkan hasil terdapatnya hubungan yang positif dan signifikan antara OCB dengan team viability. Determinasi OCB terhadap team viability sebesar $48,8 \%$ dan masih terdapat variabel lainnya yang dapat berperan dalam peningkatan team viability. Berdasarkan deskripsi data penelitian didapatkan bahwa subjek penelitian sebagian besar memiliki OCB dan team viability yang tinggi, namun terdapat pula beberapa nilai sedang hingga kurang. Dapat disimpulkan pula keberadaan 
OCB pada tim kerja dapat membantu meningkatkan team viability, sehingga dapat membantu terciptanya keefektifan tim kerja dan produktivitas perusahaan, serta berguna dalam pengembangan organisasi selanjutnya.

\section{Daftar pustaka}

Bachrach, D.G, Podsakoff, P.M., \& Bendoly. 2001. Attributions of the Causes of Group Performance as an Alternative explanation of the Relationship Netween Organizational Citizenship Behavior and Organizational Performance. Journal of Applied Psychology, 6, 1285-1293.

Baron, R. A \& Byrne, D. 2004. Psikologi Sosial (Edisi Kesepuluh). Jakarta: Erlangga.

Barrick, M.R \& Stewart, L.G. 1998. Relating Member Ability and Personality to Work-Team Processes and Team effectiveness. Journal of Applied Psychology, 3, 377-391.

Bell, S.T \& Marentette, B. J. 2011. Team viability for longterm and ongoing organizational teams. Organizational Psychology Review, 1(4), 275-292.

Griffin, M. A., Patterson, M.G \& West, M.A. 2001. Job Satisfication and Teamwork: The Role of Supervisor Support. Journal of Applied Psychology, 22, 537-550.

Gordon, T.R \& Brannick, M.T. 1999. Sailing Crews and Measures of Team Process. Paper. University of South Florida: USA.

Kreitner, R. \& Kinicki, A. 2001. Organizational Behavior. USA: Mc.Graw-Hill

Naquin, C.E \& Tynan, R.O. 2003. The Team Halo Effect; Why Teams Are Not Blamed for Their Failures. Journal of Applied Psychology, 88, 232-340.

Nawaz,N \& Gomes, A. M. 2018. Organization Citizenship Behavior and Team Performance : A Multiple Level Study in Indian Higher Education Institutions. Problems and Perspectives In Management, 16, 443-453.

Organ, Podsakoff \& Mackenzie. 2006. Organizational Citizenship Behavior: it's nature, antecedents, and consequences. New Delhi: Sage Publications.

Page, E. 2004. The Rate of Team Performance Change Over Time. Thesis. Georgia Institute of Technology: USA.

Podsakoff, P.M, Mackenzie, S.B., Paine, J.B., \& Bacrach, D.G. 2001. OCB : A critical Review of the Thereotical and empirical literature and suggestion for future research, Journal of Management, 26, 513-563.

Rentsch, J.R., Engel, E.A., Bergman, S.M., Bowler, M.C., Vernon, R.N., Zelno, A.J \& Woehr, D.J. 2003. Cognitive Congruence, Perception of Teammates and Team Viability. Paper. University of Teenesse: USA.

Riggio, R.E. 2003. Industrial and Organizational Psychology . New York : Prentice Hall. 
Yanies Novira Soedarmadi

Robbins, S.E \& Judge, T.A. 2015. Perilaku Organisasi. Jakarta : Salemba Empat.

Shachaf, P \& Hara, N. 2002. Ecological Approach to Virtual Team Effectiveness. Paper. Indiana University : USA.

Stott, K \& Walker, A. 1995. Teams, Teamwork and Teambuilding. Singapore: Prentice Hall.

Start-Up Gagal Karena Masalah Internal. (1 Agustus, 2018). Retrieved from https://www.cnbcindonesia.com/fintech/20180801190748-37-26517/65

Sundstrom. 1990. Work Teams: Applications And Effectiveness. Paper. USA. 